\title{
Contestation in Gamelan Making Rituals: Tensions between Old and New Understandings
}

\author{
Andri Handayani; Kelli Swazey \\ Universitas Gadjah Mada, Indonesia \\ Corresponding Author: andri.handayani@ugm.ac.id
}

\begin{abstract}
Performing ritual before making gamelan as one of stages of producing gamelan orchestra has changed. The decision of gamelan masters to perform ritual is affected by their worldview, socio-religious and economic changes in their surroundings. This research aims to identify contestation in gamelan making rituals especially the tensions that occur between old and new understanding of gamelan masters. The study was conducted from March 2013 to April 2015. Semi-structured interview was applied to 6 out of 10 gamelan masters in Wirun Village, Sukoharjo District, Central Java. The result finds that gamelan masters apply strategies such as purification, negotiation and commercialization to adapt to the changes in Wirun. These strategies occur based on the understanding of old and younger generation of gamelan masters in Wirun. Purification can be defined as gamelan masters attempt to purify their religious principle from other external influence. There are two types of purification conducted by gamelan masters; purification of Javanese belief and purification of Islamic teachings. Negotiation hitherto is a way for gamelan masters to perceive their religious perspective and Javanese traditions flexibly. While, commercialization is taken by gamelan masters who only perceive gamelan as an industrial commodity and who prioritize the market value disregarding religious values in making the gamelan. The strategies serve to allow gamelan masters to sustain their identity as gamelan craftsmen.
\end{abstract}

Keywords: commercialization; gamelan; negotiation; purification; ritual

\section{INTRODUCTION}

In my prior understanding, making gamelan is simply forging metal and crafting it to be some artistic Javanese musical instruments. It is an artistic work. However, after reading Ganug Nugroho Adi's 'Forging gamelan in Central Java' in the Jakarta Post explaining the ritual done by gamelan masters before making gamelan, the curiosity to explore the life of gamelan masters emerged. The author decided to go to Wirun village, a famous gamelan producing village in Sukoharjo Regency, Central Java. The reasons to choose Wirun Village as the field of research are due to the number of gamelan masters, the identity of village and the reachable access. There are about ten active gamelan masters in the village. ${ }^{1}$ This village is well-known as gamelan making center in Central
Java, Indonesia and even international scope. This can be proven from the orders coming from Japan, Malaysia, Singapore, and USA ${ }^{2}$. The access to village is a two-hour journey by motorcycle from Yogyakarta. Furthermore, gamelan masters in the village produce various kinds of gamelan so that enables to observe different making process of gamelan instruments.

Gamelan masters in producing gamelan involve religious ritual that means making gamelan is not merely usual practice but rather special and religious. In this study I do not study the extent of religiosity owned by gamelan masters. It is not dealing with the ritual showing and strengthening the identity of gamelan masters as Muslim or Kejawen adherents, but as the way how gamelan masters dealing with 
those two conditions, being Muslim and Javanese.

Since there are number of works on gamelan seen from its significance and from point of view of gamelan players, in my opinion the academic works on gamelan masters and their worldview are still few. I will explore the life of gamelan masters in Wirun, Sukoharjo Regency, Central Java. They have a worldview that I assumed as Javanese worldview which can be seen through the process of making gamelan, their understanding about their profession, and how to deal with the changing society. In the field I found that gamelan masters are trying to negotiate their profession and identity as gamelan masters amidst the changing society.

Several studies discussing spiritual matters in playing gamelan have already been conducted. One of the most well-known works is a book entitled Gamelan Stories: Tantrism, Islam and Aesthetics in Central Java written by Judith Becker. Becker focuses on the relationship between Javanese people and gamelan in everyday actions beyond the realities of human beings that embody meaning and show connections between humans and the cosmos (Becker, 1993, p. 1). Another important work about gamelan is Sumarsam's Gamelan: Interaksi Budaya dan Perkembangan Musikal di Jawa in which he also implicitly tells about the 'inner melody' in Javanese Gamelan in the foreword of the book. It means that gamelan is not only what is seen but is beyond that.

This research aims to identify contestation in gamelan making rituals especially the tensions that occur between old and new understanding of gamelan masters. It is also to describe the ways of gamelan masters to adapt to the changes in their society.

The research focuses on the worldview of Javanese Gamelan masters. The study was conducted from March 2013 to April 2015. Worldview here specifically means how they see and understand themselves and their world. It is also related to their perspective to identify themselves and their profession as well as their works; merely work of arts or tool to get money or containing religious significance. This issue (worldview) is interesting and significant to convey the condition of Javanese Gamelan masters today since they have to face two different challenges; maintaining local values/ traditions and negotiating with modernity.

To enter the world of gamelan master, participant observation approach is necessary to directly view their activities thoroughly. As Spradley mentions that participant observation is to gain greater understanding of phenomena from the point of view of participants. (DeWalt \& DeWalt, 2011, p. ix) I have no background Theknowledge about the life of Javanese Gamelan masters before. Therefore, this is one flow of information - from informants to me. Recording all the events provides natural and valid data about the process of gamelan making.

Another method, semi-structured interview was applied to 6 out of 10 gamelan masters in Wirun Village, Sukoharjo District, Central Java. They are Supoyo, Saroyo, Sutarno, Joko Dharmono, Sugeng Setiyono and Mrs. Purwanto. There are 10 gamelan masters in Wirun, but I only managed to interview 6 of them. The others did not want to be interviewed and there was no written sources discussing their perspectives. Special time to ask questions to the informants was taken. Semi- structured interview is helpful to direct the interviewees to answer the questions. However, there was no force or strict guideline during the interview. From their answers, I described and interpreted their explanation. This approach is significant to explore the worldview of gamelan masters and eventually is expected to answer the question of how they deal with modernity; still maintaining traditional/ local values or negotiating with modernity.

The term of gamelan master used here refers to a person who produces gamelan from raw materials (copper and tin) into ready-to-use musical instruments named gamelan. The identity of being gamelan master as a person involves three dimensions as Bhiku Parekh stated in his book A New Politics of Identity. As Bhiku Parekh explained that an individual has three inseparable components of identity namely: personal identity, social identity and individual identity. (Parekh, 2008, p.9)

Individual identity or overall based on Parekh's opinion is human beings belong and know that they belong to a distinct species, define themselves and decide how they should live and conduct themselves as human beings. (Parekh, 2008, p.9) Individual identity is the concept that I apply in this research because gamelan masters try to sustain their identity as Javanese, Muslim and craftsmen. I examine that the identity of gamelan masters in Wirun village influences on how they relate with other people including their negotiation in their life, in this case maintaining their existence in gamelan industry.

Worldview perspective is used to explore the understanding of gamelan masters about themselves, other beings and the relationship built between them. 
Worldview according to Robert Redfield is related to the way a man, in particular society, sees himself in relation to all else. "World view (he says) differs from culture, ethos, mode of thought, and national character...It is, in short, a man's idea of the universe. It is that organization of ideas which answers to a man the questions: Where am I? Among what did I move? What are my relations to these things? Self is the axis of 'world view.' (Redfield, 1952, p. 30)

In my opinion this relationship also occurs in the worldview of gamelan masters in Wirun. It is important to know about their identification of the self, the others and how the relationship is built among them. Some gamelan masters recognize that not only human live in the world but also other beings. It can be reflected from the result of interview, that their worldview is influenced by some factors such as religious background, social condition and life perspectives.

The concept of slamet from F. Magnis Suseno as part of Javanese worldview is used. According to Suseno, slamet is the condition as one is wellbeing when everything is in harmony. This condition depends upon appropriate conducts towards this unity of the experience of society, nature and the supernatural. (Suseno, 1997, p.86) Meanwhile Koentjaraningrat in the Javanese of South Central Java describes slamet as "a state in which events will run their fixed course smoothly and nothing untoward will happen to anyone." (Koentjaraningrat, 1960, p. 95) In my research the condition of slamet is relevant to explain the significance of ritual before making gamelan because the gamelan masters said that they hold the ritual to get blessings from God and hope their making process will run smoothly and getting good results in the end.

Javanese worldview is also related to Kejawen. Mulder in Inside Indonesian Society stated that Kejawen is a moral order with profound religious elements. (Mulder, 2005, p. 45) Furthermore, Mulder explained that Kejawen has different meaning for everyone namely; for individuals, this Kejawen means to be serious in his laku (nglakoni) in order to step in harmonious life; for others, the realization of a wise and aesthetic life conforming to morality and careful of decorum and for all, it meant self-mastery, restraint, and accommodation to a cultivated, preferably tranquil, style of life that culminated in the virtuosity of the literati and the wisdom of the king. (Mulder, 2005, p. 45) This theory is important to show the perspective of gamelan masters in Wirun since they are Javanese and have Kejawen perspective depicted in their daily activities. Some gamelan masters also do laku during ritual of making gamelan. They have to restraint their desire and master themselves. During the fieldwork I discovered a tension between these Javanese systems of belief and Islam on the relation of the self to God and the environment. Economic pressures also affected the gamelan makers' ritual practices. It is the negotiations of these tensions that will be investigated in this paper.

Citing Victor Turner's definition about a specific ritual namely religious ritual. Religious ritual according to Victor Turner is prescribed formal behavior for occasions not given over to technical routine, having reference to beliefs in mystical (or non-empirical) beings or powers regarded as the first and final causes of all effects. (Turner, 1982, p. 79)

The rituals that are commonly done by gamelan masters in Wirun Village before making gamelan will be explored. Those rituals include a slametan called Gongso Ageng Slametan, a day fasting, and refraining of having sexual intercourse in the night before making gamelan. The rituals performed by gamelan masters become a subject of debate. Since the rituals done by gamelan masters could be considered as traditional ritual (Javanese) or Islamic one depending on the people's perspective, the tensions between groups of people about this debate have emerged. One of debatable rituals is slametan. The slametan according to Masdar Hilmy is a Javanese Muslim ritual conducted to gain certain blessings from God. (Hilmy, 1999, p. 41) The slametan is usually done to celebrate passages of life such as pregnancy, birth, circumcision, marriage, and death. The slametan is also done to celebrate other events such as name change, establishing new house, bersih desa, job promotion, successful events in life.

The discussion about slametan is closely related to the debate whether it is Islamic of not. This debate has been initiated by two prominent scholars of Javanese studies; Clifford Geertz and Mark Woodward. Citing from Hilmy, Geertz defines the slametan as the Javanese religious ritual indicated by communal feast symbolizing the mystic and social unity of those taking part in it. (Hilmy, 1999, pp. 4142) In other words, Geertz states that the slametan is animistic ritual that aims at strengthening social solidarity among Javanese people. Meanwhile, Woodward states that the slametan is "a ritual meal at which Arabic prayers are recited and food is offered to the Prophet Muhammad, saints and ancestors, who 
are implored to shower blessings on the community." (Woodward, 2011, p. 113; Woodward, 1988, p.54) From his statement, we can see that Woodward clearly defined the slametan as an Islamic ritual. Although the scholars discovered their own definition about the slametan, this ritual has already changed following the change of society. Similarly, other rituals that gamelan masters do before making gamelan inevitably ignite tensions among society.

As my last notion, the factors that influence gamelan masters in making their gamelan are including social changes, orders from buyers and their religious worldview. Social condition in Java especially has been changing. Joko Dharmono in interview said, 'daerah Sukoharjo dingge pertanian malah dibuat pemukiman', means that Sukoharjo district was used to be agricultural field and now is changed into settlement. According to Geertz, modernized industrial societies come to resemble one another more and more closely as they develop, not merely in their economic functioning but in their type of value system, sort of class structure, pattern of government, even in their family organization and their religious belief. (Geertz, 1963, p.143) The process of making gamelan has also been changing from time to time. The present gamelan masters in Wirun have different ways to make gamelan from their predecessors. Previously the ritual of making gamelan was only Gongso Ageng Ritual but now many forms of ritual are done by gamelan masters ${ }^{3}$. The buyers also play important roles to determine the process of making gamelan since today there are many modification in gamelan instruments. The process here also includes the need to hold a ritual before making gamelan. The buyers also can determine the time, offerings and materials that will be included in the ritual. Recent changes in both the use of gamelan as an object for purchase, as well as the concern over practices deemed non-Islamic, are challenging the worldview of Gamelan makers. In this paper, I am investigating how these craftsmen negotiate these pressures as they continue to produce Gamelan orchestras as an inherited livelihood.

\section{FINDINGS AND DISCUSSION}

\section{Rituals and Change}

Rituals of making gamelan in Wirun village are not static. They have been developing in accordance with the worldview of gamelan masters in Wirun. The worldview of gamelan masters also develops following the changes in society. The pioneers of gamelan master in Wirun used to conduct certain Kejawen rituals to initiate gamelan-making process. Kejawen rituals here mean that certain laku (refraining self) and slametan are based on traditional Javanese belief. Those rituals as explained above such as fasting, staying up late and slametan were believed to support the success of gamelan making process.

However, rituals of making gamelan have changed. The changes can be seen from the methods, types, beliefs and participants. Some gamelan masters even decide to not perform any ritual before making their gamelan. According to Joko Dharmono, the prayers used in slametan were in Javanese language not Arabic as today's slametan. He said that his father used the Javanese prayers during Gongso Ageng Slametan. Citing Geertz from Hilmy, slametan was Kejawen ritual that embodied the spiritual notion and social integration that go hand in hand and support each other. (Hilmy, 1999, p.42) At that time, Javanese people understood religion as syncretistic form of Javanese religions and their conception of God was ambiguous mix of mBah Buda (a God in Budhhist context) and other forms of spirit beliefs such as memedis, lelembuts, dhemits and dhanyangs. (Hilmy, 1999, p.45) Today, Gongso Ageng Slametan uses Arabic prayers (doa) taken from the Koran and Hadith and it is intended to God only to ask for blessings and the success of gamelan making process. The food served in the slametan that was completed by incense and water steeped with flowers petals, now those elements are eliminated. Therefore, in slametan gamelan masters provide ingkung, cone-shaped rice, side dish (tempe, tofu, gudangan), jajanan pasar (traditional snacks) and banana (usually Pisang Raja is used).

The second change is about the types of slametan before making gamelan done by gamelan masters in Wirun village. The slametan ritual that was conducted by most gamelan masters in Wirun Village was Gongso Ageng Slametan. Hence, in Wirun village today, gamelan masters have their own ritual before making gamelan based on their belief. The rituals vary from Gongso Ageng slametan, fasting, stayingup at night and refraining to have sexual intercourse with their wife.

The variation of rituals of making gamelan is caused by several matters. The first is their belief about the efficacy of certain ritual on the success in making gamelan. For instance, Supoyo believes that only Gongso Ageng slametan is effective to support 
the success of making Gong Ageng with a meter wide. On the other hand, Joko Dharmono is sure that fasting is the best ritual before making gamelan. Another gamelan master, Sutarno said that he believes by staying-up at night and not having sexual intercourse with his wife, he will be able to make a good gamelan set in the next morning. Those examples show that even before making gamelan, the gamelan masters rely on their rasa on how they feel and certain about the success of gamelan making process. By having rasa of certainty about the success of making process, it will motivate the gamelan master to do their best during the making process since the process of making gamelan is hard in a very hot besalen as seen in figure 1. The rasa is contextualized in the form of ritual before making gamelan. They feel more certain and motivated about the success of making gamelan by using ritual rather than the gamelan which do not have any ritual in the making process. Rasa becomes part of their worldview in seeing gamelan. Gamelan must be treated specially through the ritual though each of them has their own ritual.

Figure 1. Workers are working in besalen (Photo by: Andri Handayani, 2013)

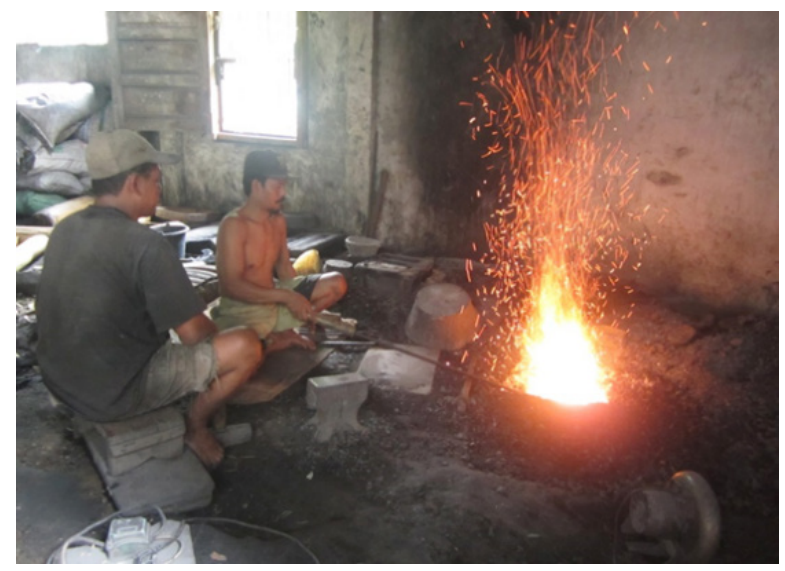

The second reason of ritual variation is inability to perform Gongso Ageng Slametan. Not all gamelan masters in Wirun village at present understand how to hold Gongso Ageng slametan. Although most of their parents were also gamelan masters who practiced Gongso Ageng slametan during their lifetime, some gamelan masters in Wirun today do not practice the slametan by themselves. The third reason is socio-religious discourse emerging in their village. Some gamelan masters leave the slametan because it is bothering and complicated. With the condition of nowadays which considers "time is money", preparing foods and equipment for slametan will waste energy, time and money. The variation in holding rituals before making gamelan making and inability to perform Gongso Ageng slametan make some gamelan masters to decide not performing any rituals in making gamelan. This variation of ritual practice triggers a contestation between gamelan masters about the importance of slametan and ritual before making gamelan.

\section{Contestation in Gamelan Making Rituals}

Rituals of making gamelan have already changed in Wirun Village. The pioneers of gamelan master in Wirun used to conduct certain Kejawen rituals to initiate gamelan making process. Kejawen rituals here mean that certain laku (ascetic activities/ refraining self) and slametan are based on traditional Javanese belief. Those rituals as explained above such as fasting, staying up late and slametan were believed to support the success of gamelan making process. Today, based on the interview, not many gamelan masters practice Kejawen rituals before making gamelan. They do not practice rituals before making gamelan due to several reasons. The reasons are they cannot perform the rituals especially slametan and the social pressure in the village.

\section{Inability to perform the rituals}

Today some gamelan masters in Wirun cannot conduct Kejawen slametan. This condition is caused by the focus on regeneration is on the technical method to make gamelan not on the spiritual principle in the making process. The interviewed gamelan masters said that their predecessors of gamelan masters used to do certain rituals in making gamelan. As Supoyo said, 'Nek gong besar itu yang sudah sudah memang sejak dulu zaman bapak kulo pun ngoten. Bapak kulo pun nate meling yen gong sak meter ki ojo ninggalke adat Jowo'. Sutarno also said that 'ritual Gongso Ageng dulu nggih. Sekarang peralihan peradaban.' However, they do not inherit the tradition of doing slametan from their parents except Supoyo.

Inability in performing rituals does not influence on the gamelan making process now, for some gamelan $m$ asters. Saroyo said that there is no trouble coming in making gamelan without ritual. The making process is still successful. Mrs. Purwanto also said that her husband also does not perform any rituals in making gamelan because he does not 
understand the way to do the ritual. Sutarno also said that the slametan used to do before his generation. Now, gamelan masters cannot perform the ritual by themselves except some masters. If the buyers want to hold the ritual, the gamelan masters usually call abdi dalem keraton (the Palace servants) to perform it.

\section{Social pressure in the village}

Another reason gamelan masters in Wirun village give for not performing rituals before making gamelan is based on the socio-religious discourse in their environment. Gamelan masters think that people consider the rituals of making gamelan to be un-Islamic. In fact, this issue is very sensitive to be discussed and the gamelan masters used soft statements to express their view about religious discourse in slametan. The debate is about whether the slametan is more Islamic or Javanese (Kejawen) ritual. People argue the ritual performed by the gamelan masters is Javanese (Kejawen) ritual rather than Islamic one. However, Joko Dharmono, Supoyo and Saroyo said that Gongso Ageng slametan is Islamic because the prayers used in the slametan are taken from the Koran and the leader in the slametan is the ulama or modin.

Meanwhile, in the village there are some Islamic groups developing such as Nahdlatul Ulama (NU), Muhammadiyah and MTA. Nahdlatul Ulama and Muhammadiyah are two mainstream Islamic groups in Indonesia. (Wanandi, 2002, p. 105) Moreover, Woodward said that Nahdlatul Ulama is the largest Islamic organization in Indonesia and one of the largest ones in the world. (Woodward, 1998, p. 899) The history of Muhammadiyah was started in 1912 and initiated by Ahmad Dahlan, who was a religious teacher and Batik cloth manufacturer in Jogjakarta. (Hamka, 1952, p. 13 in Palmier, 1954, p. 257) Meanwhile, Nahdlatul Ulama (NU) was established by K.H. Abdul Wahab Hasbullah and K.H. Hasyim Asy'ari on 31 January 1926 in Surabaya, East Java. (Ismail, 2011, p. 247)

Muhammadiyah follows ideology of Modern Islam whereas NU takes traditional Islam as their ideology. They also take different approach to propagate Islamic teachings. Muhammadiyah has been struggling to "purify" Islam especially to educate and modernize Muslim. (Wanandi, 2002, p. 105; Fuad, 2002, p. 133) To achieve educated and modern Muslim, Islam has to eliminate animistic beliefs which hamper modernization and development. (Wanandi, 2002, p. 105-106; Maarif, 1985, pp. 52-79 and Noer,
1980, pp. 37-179 in Fuad, 2002, p. 134; Palmier, 1954, p. 258) Muhammadiyah not only intends to develop good Muslim, pious men, but also independent people. (Palmier, 1954, p. 258) On the other hand, animistic beliefs and traditions deprive Muslim from being independent and developed. Therefore, Muhammadiyah tries to purify Islam from other foreign substances that are not in accordance with $\mathrm{Al}$ Qur'an and Hadith (Sunnah/ tradition of the prophet). One of traditions that are opposed by Muhammadiyah is Javanese slametan.

Meanwhile, Nahdlatul Ulama takes different path from Muhammadiyah. Nahdlatul Ulama has goal "to hold firmly one of the four madhahib: the Hanafi, the Maliki, the Shafiei, and the Hanbali school, and to carry out its program which benefits Islam." Besides Al Qur'an and Hadith, NU also uses the books of ulama as relevant tools in understanding Islamic law. (Ismail, 2011, p. 254-255) NU has its central strength; ulama for two reasons. The first, as religious organization, $\mathrm{NU}$ derives basic power from morally and religiously guaranteed figures, and they are the ulama. Secondly, the ulama have power among the santries, former santries and larger communities even in rural areas. Moreover, According to William Liddle, NU leaders generally assert that the success of Islamic proselytization is due to adaptation of Islamic teachings to local culture instead of forcing Indonesian to absorb Middle-Eastern style Islam. (Liddle, 2003, p.6) In Wirun case, the influence of $\mathrm{NU}$ is also seen from the stance of gamelan masters about the ritual of making gamelan that they practice. Joko Dharmono said that regarding religious tensions developing in his village, he criticized Muhammadiyah that does not respect Javanese tradition. In the perspective of Joko Dharmono, religion and tradition is separated. They have their own way. It will be ruined if they unite or eliminated.

From Joko Dharmono's statement, it can be infered that there are Islamic groups that are tolerant and intolerant to Javanese culture and tradition. Based on his explanation, Joko Dharmono prefers to Islamic group who is more tolerant to the Javanese culture that is NU although he is not a participant of this organization.

The gamelan masters in Wirun feel anxious to be labeled as "deviant" if continuing to practice the ritual which is considered as more traditional Javanese rather than Islamic. Their anxious faces were portrayed during the interview. During the interview, only one gamelan master joins Islamic group namely 
MTA (Majelis Tafsir Al Qur'an). The participation in Islamic group influences on the view in making gamelan. Nowadays, she only makes Balinese style gamelan which does not need rituals during the making process. This is done to avoid improper activities that are not in line with Islamic teachings, since she considers the slametan as non-Islamic act. She wants to purify all non-Islamic activities from not only the process of making gamelan but also all aspects of her life such as the way to dress (appearance), piety in practicing religious rituals and the way to relate with other people.

However, religious discourse developing in Wirun village already influences gamelan masters on expressing their religious perspective to other people. During the interview, the gamelan masters seemed reluctant to express their religious perspective especially regarding to the ritual before making gamelan that they practice. This expression can be seen from their way of speaking that used polite expression such as (nyuwun sewu, maaf lho ya) which means sorry. Perhaps their way of speaking will be different if I don't wear hijab. This non-verbal communication is a form of reluctance because they feel what they express maybe is not proper in Islamic view. Therefore, they seemed to be careful in delivering their opinion about the ritual of making gamelan.

From this data, I can conclude that the decision to hold a slametan before making gamelan is also influenced by socio-religious pressure from society. The pressure includes the perspective of society in the village about the ritual before making gamelan that is more Javanese and mystical rather than Islamic. The label of "deviant activity" makes gamelan masters consider their stance to hold gamelan. The perspective to purify Islamic teaching also becomes trigger to them not to have the slametan before making gamelan.

\section{Tensions between Old and New Understandings}

Old understanding meant in this paper is the understanding owned by former gamelan masters in Wirun village regarding the implementation of ritual before making gamelan. The former gamelan masters were Reso Wiguno and old generation who already passed away. In their perspective, performing Gongso Ageng ritual before making gamelan was a must to guarantee the success of making process. However, according to some of existing gamelan masters, conducting ritual before making gamelan is optional and the forms of ritual can be varied based on the belief of gamelan masters. This understanding is referred as new understanding.

The biggest reason behind the existence of the gamelan industry in Wirun is supply and demand. The author asked gamelan masters about the cultural preservation motive behind their existence. Supoyo answered definitively want to preserve the existence of gamelan, but it is impossible without orders from the buyers.

However in matter of holding ritual before making gamelan, gamelan masters have different reasons. Supoyo said whether or not the buyers order to hold a ritual, he certainly holds it. This is especially for making Gong Ageng. He always holds ritual since he believes that the success of making Gong Ageng depends on the ritual itself. He does not mind to spend money to hold the ritual.

Besides, for Supoyo holding Gongso Ageng slametan is a tradition inherited from his father. His father told Supoyo "when you get order to make a Gong Ageng, you must hold Gongso Ageng slametan. Don't leave the slametan." His father's legacy is strengthened with the experience of failure in making gamelan without the ritual. Nevertheless, another gamelan master, Saroyo said that he will do the ritual if the buyers tell him so. If they do not ask him to hold a ritual/slametan, he won't do it. While, other younger generation of gamelan masters such as Sutarno and Sugeng Setiyono said that they do not hold slametan though they have different rituals.

Internal and external factors influence gamelan masters on deciding their stance about rituals before making gamelan and their perspective about gamelan. The internal factors influencing them are their worldview and religious tradition they profess. Meanwhile, the external factors that influence gamelan masters are socio-religious discourses in the society and market demands. From those factors, I can categorize the stances of gamelan masters into three types: purification, negotiation and commodification.

Purification means that gamelan masters want to purify their principle from other external influence. For the case of Supoyo who still holds Gongso Ageng slametan, he wants to purify the principle of continuing Javanese legacy and "tolak bala" (averting evil). He doesn't want to change although there is social pressure in the village. In contrast, Ari Estuti's family who is also the successor of her father, Samsiyo (one of gamelan master in Wirun) chooses to purify 
the process of making gamelan from any Javanese ritual. She thinks that the rituals of making gamelan are not appropriate with Islamic teachings. Therefore, she does not perform any rituals in the process of making gamelan. Religious principle is held tightly and it underlies the understanding of gamelan masters about the rituals.

In purification case, the need to show piety in public is seen especially in two opposing parties: Javanese tradition or Islamic purification. Citing Hasan in his article the rising Islamic militancy in Indonesian public sphere triggers Indonesian Muslim to accentuate religious symbols and the proliferation of Islamic institutions and new life-styles. (Hasan, 2009, p. 230) Hasan gives examples of the trend of Islamic proliferation such as more constructions of mosques, mushrooming of Quranic reading sessions (pengajian), more people performing hajj, more Muslim women wear jilbab, more Muslim men wear koko, consumption of halal product and Islamic music. However, the most important things for the Islamic public piety are the awareness of Muslim to embody Islamic teachings and show their piety in their daily life as "an expression of identity and representation of the self". (Hasan, 2009, p. 241) We can see this attitude from the case of Ari Estuti. She refuses using ritual in making gamelan, practices salat (the five daily prayers), provides mushola in her house, and wears jilbab in daily life. These are efforts to show her piety in public and as a means to strengthen her identity as a pious Muslim.

Similarly, in the case of Supoyo, Joko Dharmono and Sutarno, they still maintain the ritual of making gamelan to express their identity as Javanese gamelan masters who still maintain Javanese tradition that is transmitted from their parents. This does not meant to show their piety in public or strengthened their religiosity, but more to represent their identity as Javanese. In this case, they consider Javanese tradition as native tradition that should be maintain or purify from foreign tradition.

The second stance is negotiation. Negotiation means that gamelan masters do not see their religious principle as rigid matter. It can be flexible. The case of Saroyo is the example on how negotiation is applied. According to Saroyo ritual of making gamelan is good but the process of making gamelan still can run without rituals. He agrees to call slametan as Islamic ritual because it uses prayers taken from the Koran. However, now he cannot practice the ritual by himself because his parents did not inherit it to him. He also wants to avoid bad comments addressed to him by not performing Javanese ritual. On the other hand, Saroyo also doesn't refuse buyers who order gamelan using slametan to him.

Another case is presented by Sutarno who agrees the implementation of rituals before making gamelan. He said that the rituals of making gamelan are similar to rituals in Islamic tradition from the purpose/ aim. Although the activities and methods from both rituals are different, the purpose or essence of the rituals is the same; to memorize God. Negotiation done by Sutarno is comparing two kinds of rituals to see the similarity. In this case, Sutarno compares between having Javanese rituals and dzikir. The similarity between two things will result closer relation between them. From Sutarno's statement, it can be inferred that his position in the debate of Islamic and Non- Islamic rituals is "in between position" as he does the ritual before making gamelan yet also implements Islamic tradition.

The third stance is commodification or commercialization of gamelan. The gamelan masters in Wirun village are aware that the gamelan is national heritage. Their gamelan is well-known nationally and globally. Countries that order their gamelan are such as USA, Malaysia, Singapore, Germany, New Zealand, Japan, etc. In marketing their gamelan, gamelan masters use word-of-mouth marketing. Although they do not use sophisticated marketing promotion, they still get many orders. Usually gamelan masters have already had loyal subscribers for their gamelan. Between gamelan masters, they often consider each other as "family". Commodification in this case is done by using names of more popular gamelan masters to elevate the sale of their gamelan. For example, Mrs. Purwanto says to the candidates of buyer that Supoyo is her uncle so the quality of gamelan that she makes is quite similar to Supoyo's work. On the contrary, Supoyo is not happy with that.

\section{CONCLUSION}

Interactions with other groups groups changes their religious views. As gamelan masters who get many orders from various group of people, they understand that other religious institutions order their gamelan as musical instruments to be used in worship places. They think it is the evidence that other religious institutions respect gamelan more than Islamic institutions. This is a form of self-critique since they also become part of Islam itself. The self-critique was also delivered as 
form of their dissatisfaction about intolerance of Islam to culture and arts. Therefore, in the end they conclude that religion and culture should remain separated in order to achieve a harmonious life.

Since socio-religious and the economic environment changes their worldview, gamelan masters have strategies to face the changes in their village. The strategies are negotiation, purification and commercialization.

The dynamics in the gamelan industry encourage gamelan masters to maintain their identity as masters of gamelan, and the craftsmen of gamelan. The important matter to maintain also is their ability to make gamelan which includes rasa. The ability of making gamelan is also connected to their religious and spiritual beliefs about the process. They said that to produce a good gamelan set must take a longenergy consuming process and needs rasa in it. Rasa is used as the core in making gamelan starting from selecting materials, forging process until the tuning process. Utilizing rasa is also the way to contextualize their worldview on seeing gamelan; as the product of skills, rasa and arts. Their anxiety of failure in making Gong Ageng whether or not affects their religious perspective about ritual of making gamelan. The strategies of gamelan masters to exist in their environment amidst the tension between socioreligious and also economic discourses are similar to James Clifford's statement "indigenous articulation".

James Clifford researched Kanaks community, native population in New Caledonia and found that they live and work in both villages and cities. In the research, Clifford focuses on the "indigeneity" "that is both rooted in and routed through particular places, relations between "edge" and "center", and to what extent the notions of indigenous or native affiliation become before they begin to lose specificity. (Clifford, 2001, pp. 469-470) Indigenous articulation is defined as deeper sense of political - productive processes of consensus, exclusion, alliance and antagonism that are inherent in the transformative life of all societies. (Clifford, 2001, p. 473) In this case, the Kanaks community is still rooted to "their land" as their home though they already develop and transform. They can negotiate their position as natives and the people who do their work in both places; the villages and the cities. The feeling of being rooted in the villages is still articulated in their present daily life indicated by commuting from the villages to the cities, vice versa for working and living. Similarly yet little bit different, this attitude is also seen from the purification strategies done by Supoyo, Joko Dharmono and Sutarno who still maintain their Javanese belief in making gamelan. Although the time changes and the life also changes they still maintain the legacy and their belief in performing rituals before making gamelan. They are still rooted in Javanese tradition as Javanese people.

The tension between religious perspectives about certain ritual becomes common today since the purification movements of religious teachings, especially World Religions are increasing in importance. The need to express piety in public becomes stronger since people are aware of the importance of embodying religious teachings in life, not only in the context of religious rituals but also in daily activities such as dressing up, dietary patterns, consuming products, etc. On the other hand, for people who are aware that they need to maintain their tradition as a legacy from their parents, it is important to maintain the traditions as part of representing their identity as descendants of their predecessors. However, the differences in religious perspectives cause tension and conflict, though it is not always apparent on the surface.

\section{ENDNOTES}

1) The active gamelan masters in the village are Supoyo (the successor of Rekso Wiguno), Saroyo, Djoko Dharmono, Purwanto, Sutarno, Ari Estuti (the successor of Samsiyo), M. Sahli, Supomo, Sanjaya, and Hadi Wiyono. Retrieved from http://gamelanwirun.blogspot. com/p/contact-us.html

2) Based on the interview with Saroyo, Supoyo, Sutarno, and Djoko Dharmono conducted from 2013 until 2015. 3) Interview with Sutarno. Dulu nggih. Sekarang peralihan peradaban. Kalo sekarang ya kalo malam nyuwun sewu nggih. Jangan kumpul sama istri sama ga tidur sore. Bolehnya setelah jam 12 kadang sampe pagi. 4 ) the quality of being indigenous $(N)$, in a similar way, "indigeneity" is derived from "indigenous" which means born or produced naturally in a land or region; native or belonging naturally to (the soil, region, etc.)," from indu, an old Latin root meaning "within" (like the Greek ..., endon) and gignere meaning "to beget." Retrieved from http://icl.googleusercontent.com/?lite url=http:/www. definition-of.com/indigeneity\&ei $=\mathrm{Gt}-\mathrm{rMctW} \& \mathrm{lc}=\mathrm{id}-$

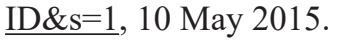

\section{REFERENCES}

Becker, J. (1993). Gamelan Stories: Tantrism, Islam 
and Aesthetics in Central Java. Arizona: Arizona State University.

Clifford, J. (2001). Indigenous articulations. The Contemporary Pacific, 13(2), 467- 490.

DeWalt, K. M. \& DeWalt, B. R. (2011). Participant observation: A guide for fieldworkers. Rowman Altamira.

Fuad, M. (2002). Civil society in Indonesia: the potential and limits of Muhammadiyah. Sojourn: Journal of Social Issues in Southeast Asia, 133-163.

Hasan, N. (2009). The making of public Islam: piety, agency, and commodification on the landscape of the Indonesian public sphere. Contemporary Islam, 3(3), 229-250.

Hilmy, M. (1999). Islam and Javanese Acculturation: Textual and Contextual Analysis of the Slametan Ritual. Master Thesis. Montreal: McGill University Library.

Ismail, F. (2011). THE NAHDLATUL ULAMA: Its Early History and Contribution to the Establishment of Indonesian State. Journal of Indonesian Islam, 5(2), 247-282.

Koentjaraningrat (1960). The Javanese of south central Java. Wenner-Gren Foundation for Anthropological Research, Incorporated.

Liddle, W. R. (2003). New Patterns of Islamic Politics in Democratic Indonesia. In Amy McCreedy, Piety and Pragmatism: Trends in Indonesian Islamic Politics (Washington, D.C.: Woodrow Wilson International Center, Asia Special Report, no. $10,2003)$

Maarif, A. S. (1985). Islam dan masalah kenegaraan: studi tentang percaturan dalam konstituante.
Lembaga Penelitian Pendidikan dan Penerangan Ekonomi dan Sosial.

Magnis-Suseno, F. (1997). Javanese ethics and worldview: The Javanese idea of the good life. Jakarta: Gramedia Pustaka Utama.

Mulder, N. (2005). Inside Indonesian society: cultural change in Java. Yogyakarta: Kanisius.

Palmier, L. H. (1954). The Muhammadiyah After Independence, Pacific Affairs, (27)3, p. 257.

Parekh, B. (2008). A new politics of identity: Political principles for an interdependent world. Palgrave Macmillan.

Redfield, R. (1952). The primitive world view. Proceedings of the American Philosophical Society, 96(1), 30-36.

Turner, V. W. (1982). From ritual to theatre: The human seriousness of play. Paj Publications.

Wanandi, J. (2002). Islam in Indonesia: Its History, Development and Future Challenges. Asia Pacific Review, 9(2), 104-112.

Woodward, M. R. (1988). The" Slametan": Textual Knowledge and Ritual Performance in Central Javanese Islam. History of Religions, 54-89.

Woodward, M. R. (1998). Nahdlatul Ulama, Traditional Islam and Modernity in Indonesia. Edited by Greg Barton and Greg Fealy. Clayton, Australia: Monash Asia Institute, 1996. xvii, 293 pp. The Journal of Asian Studies, 57(03), 899-900.

Woodward, M. R. (2011). Java, Indonesia and Islam (Muslims in Global Societies Series). Springer Netherlands. 